\title{
Scale, Scope, and Specialization Effects on Retailers' Procurement Strategies: Evidence from the Fresh Produce Markets of São Paulo
}

\author{
Denise Y. Mainville* \\ Thomas Reardon** \\ Elizabeth M.M.Q. Farina***
}

Resumo: Ao redor do globo, a emergência de grandes cadeias de supermercado em mercados alimentícios de varejo é frequentemente associada à marginalização de varejistas menores. Uma notável exceção existe no Brasil, porém, onde pequenos varejistas têm mantido sua posição no mercado e, recentemente, até ganharam espaço. A literatura investigando como a concentração do varejo afeta cadeias produtivas de alimentos como a concentração no varejo tem afetado as cadeias de agroalimentos tem enfocado atividades das cadeias de varejo maiores. Fatores como escala, escopo e especialização dos varejistas em termos de insumos têm sido mantidos implicitamente constantes, ignorando a influência desses fatores nas estratégias de compra dos varejistas..Os dados foram obtidos junto a varejistas da São Paulo metropolitana. Os resultados da pesquisa consideram atores responsáveis por estratégias varejistas de obtenção e o tradeoffs entre as opções, bem como justificam a hipótese essencial do artigo de que pesquisa acerca das estratégias competitivas de varejo, em um contexto de dominação de mercado por grandes varejistas, não deveria enfocar exclusivamente o matiz com o qual varejistas menores imitam os maiores. Antes deveria contemplar a possibilidade de as características inerentes aos varejistas tornarem adequadas estratégias competitivas divergentes.

*Department of Agricultural \& Applied Economics - Virginia Polytechnic Institute \& State University. mainvill@vt.edu

**Department of Agricultural Economics - Michigan State University. reardon@msu.edu

***Dept. of Economics - University of São Paulo. emmqfari@usp.br 
Palavras-chave: escala, leque, estratégias de aquisição, produto fresco, varejo.

Classificaçao JEL: L22

Abstract: Worldwide, the emergence of large supermarket chains in food retail markets is often associated with the marginalization of smaller retailers. A notable exception exists in Brazil, however, where small retailers have held their place in the market and recently even gained ground. The literature investigating how retail concentration has affected agrifood chains has focused activities of the largest retail chains, implicitly holding the scale, scope and specialization of retailers' input needs constant, and overlooking the influence of these factors on retailers' procurement strategies. This paper tests hypotheses regarding these variables' effects on retailers' fresh produce procurement strategies. Data is drawn from a survey of retailers in metropolitan São Paulo. The research results provide insight into factors underlying retailers' procurement strategy choices and tradeoffs among options. The results support the fundamental hypothesis of the paper that research on the competitive strategies of smaller retailers in a context of market domination by large retailers should not focus exclusively on the degree to which the smaller retailers imitate the larger retailers rather it should account for the possibility that the underlying characteristics of the retailers may make diverse competitive strategies appropriate.

Keywords: scale, scope, specialization, procurement strategy, fresh produce, retail

JEL Classification: L22

\section{Introduction}

Brazilian agri-food markets, reflecting worldwide trends, have seen the emergence of large chains of supermarkets and hypermarkets as dominant players. The competitive strategies of these large chains have wrought major changes in the structure and performance of agrifood markets, not 
only at the retail level but also along the marketing chain to the farm level. Although the rise of large, modern supermarket and hypermarket chains is associated with the marginalization of many small and more traditional retailers in many countries' markets (for example see Arnole \& Luthra 2000; Reardon \& Berdegue 2002), a notable exception exists in Brazil, where small chains and independent supermarkets of diverse formats have managed to not only persist in the market, but also gain ground relative to the large chains (Farina, Nunes et al. 2004). Currently two categories of food retailers can be generalized as existing in Brazil-large modern supermarket and hypermarket chains and smaller, more traditional retail formats (such as open-air fairs, independent supermarkets, and green grocers). These different types of retailers compete through their merchandising and procurement strategies, however only limited research exists about how differences in their merchandising and procurement strategies contribute to the coexistence of diverse retailers. This research investigates the determinants of retailers' procurement strategies, complementing existing work on Brazilian retailers' merchandising strategies (for an example, Farina et al 2004).

Literature on the rise of large chains has focused on how their competitive strategies have affected upstream market structure and performance, particularly through their shifts in procurement strategies (Loseby, 1997; Green, 2000; Farina, 2002). By focusing almost exclusively on large chains and their strategies, the literature has implicitly held the scope, scale, and specialization of retailers' input needs constant, thus overlooking the influence of these factors on retailers' procurement strategies. Meanwhile, research considering the role of smaller retailers (both supermarket and non-supermarket formats) has often sought to document the extent to which they have emulated large chains' strategies (e.g. Shaw, 1999) but not explicitly modeled how the underlying characteristics of these firms, including scope, scale, and specialization, affect the strategies that they do use. The implicit assumption in these works is that a dominant strategy will emerge and that those who cannot or do not adopt that strategy will struggle to compete.

This paper examines the effects of scope, scale, and specialization on procurement strategies, taking the stance that these variables influence the firms' procurement strategies and, therefore, the firms' competitiveness. 
Two research questions are addressed: 1) How do scale, scope, and specialization affect retailers' choice of organization, source, and governance of the produce procurement strategies? 2) Given the effects of scale, scope and specialization on specific aspects of procurement strategies, what patterns of procurement strategies emerge and how are these related to differences in scale, scope and specialization among retailers?

The paper treats procurement as a meta production function reflecting product transformation by retailers from an intermediate good purchased from a supplier to a final product for sale to the consumer. Treating the choice of procurement system as an adoption decision that requires different fixed and variable expenditures, we decompose the costs (transaction, transformation, and intermediate product) of alternative procurement systems to examine tradeoffs that might exist among different types of costs. Hypotheses are addressed using statistical tests for differences in means between groups. Data are drawn from a 2002 survey of 33 retailers in metropolitan São Paulo.

The paper challenges the notion that a single competitive procurement strategy model will emerge - that is, not all retail firms are following the same path to "modernization" as might be assumed by ignoring the scope, scale, and specialization effects. We use tomato and lettuce procurement in São Paulo as an example. Lettuce and tomato are two of the most important horticultural products produced and consumed in the São Paulo area, yet their marketing chains are vastly different due to the characteristics of each product. Lettuce is a highly perishable product and is manually graded at the farm, and so frequently moves direct from the production areas to retail stores. In contrast, tomato is relatively less perishable and also amenable to mechanical classification, so it more frequently passes through classification and distribution facilities between the farm and retail store. These primary differences and other minor ones affect the costs and benefits of different procurement strategy options, so are treated separately in the paper.

\section{Empirical Context}

We use tomato and lettuce procurement in São Paulo as an example. Due to their high perishability and infrastructure constraints, as well 
as the significant demand presented by metropolitan São Paulo, most of the lettuce and tomato produced in São Paulo state is consumed in greater metropolitan São Paulo. Metropolitan São Paulo is a city of approximately 18 million residents. Supermarket chains accounted for $70 \%$ of food retail sales (for in-home consumption), while independent self-service retailers accounted for $25 \%$ and traditional full-service retailers the remaining $5 \%$ (Farina, Nunes et al 2004). Supermarket chains' share of fresh produce markets tend to be about $2 / 3$ their share of food retail (Reardon and Berdegue, 2002), such that these are responsible for an estimated $46 \%$ of fresh produce sales in Metropolitan São Paulo. More precise recent figures on the share of different retail types in fresh produce sales are not available.

São Paulo is home to a diversity of retailers, reflecting a broad range of scales, scopes, and degrees of specialization. For the purpose of illustration, four types of retailers can be generalized as active in São Paulo's fresh produce markets, together representing chain, independent and traditional retailers. The first group includes large, modern supermarket and hypermarket chains. These firms are generalline merchandisers, carrying both food and non-food items. Though they do not specialize in fresh product markets, their scale tends to be very large, as can their scope. The second group includes small and medium supermarkets which exist as independent firms or in small chains. These are also general-line merchandisers and as such do not specialize in fresh products. Both their scale and scope tend to be small, but scope may vary broadly. The third group is discount green grocers. These firms are specialized in sales of perishables, with a strong or even exclusive focus on fresh products. They tend to be large scale but have a relatively limited scope, reflecting their discount orientation. Finally, there are the small scale open-air fair vendors who specialize in fresh produce. These generally tend to focus on sales of only one segment of the fresh product market, for example leafy greens, thus their scope also tends to be very small. The characteristics of the different retailers with respect to scale, scope, and specialization are summarized in Box 1. Scale is represented by the floor sales space allotted to fresh fruits and vegetables (Total FFV m2) aggregated across all stores. Scope is represented by the total number of fresh fruit and vegetable items sold 
by the retailer. Specialization is represented as the total percentage of a firm's revenue that is accounted for by fresh produce sales, with higher shares of fresh produce sales representing higher degrees of specialization.

Box 1. Scale, scope and specialization of São Paulo's fresh produce retailers

\begin{tabular}{|l|c|c|c|c|}
\hline & $\begin{array}{c}\text { Supermarket } \\
\text { \& } \\
\text { Hypermarket } \\
\text { Chains }\end{array}$ & $\begin{array}{c}\text { Small and } \\
\text { Medium } \\
\text { Supermarkets }\end{array}$ & $\begin{array}{c}\text { Discount } \\
\text { Green } \\
\text { Grocers }\end{array}$ & $\begin{array}{c}\text { Open-Air } \\
\text { Fair Vendors }\end{array}$ \\
\hline Scale & Large & Small & Large & Small \\
Mean/Std. Dev. & $39,188 / 13,955$ & $202 / 134$ & $\begin{array}{c}2,473 / \\
1,241\end{array}$ & $23 / 3$ \\
$\begin{array}{l}\text { Total FFV m2 } \\
\text { for firm }\end{array}$ & Large & Small & Small & Small \\
\hline $\begin{array}{l}\text { Scope } \\
\text { Mean/Std. Dev. } \\
\begin{array}{l}\text { Average items } \\
\text { per store }\end{array}\end{array}$ & $377 / 32$ & $232 / 105$ & $111 / 16$ & $42 / 6$ \\
\hline $\begin{array}{l}\text { Specialization } \\
\text { Mean/Std. Dev. }\end{array}$ & Low / 1\% & $15 \% / 4 \%$ & $89 \% / 5 \%$ & $94 \% / 6 \%$ \\
$\begin{array}{l}\text { Firm revenue } \\
\text { from FFV }\end{array}$ & Low & High & \\
\hline
\end{tabular}

Source: Authors' survey data.

\section{Conceptual Framework, Implementation Model \& Hypotheses}

The procurement strategy is comprised of the mix of organization, institutional arrangements, and sources used in the acquisition of produce and its transformation from an intermediate good purchased by the retailer to a shelf-ready product. In this respect, the procurement strategy choice can be conceived of as analogous to a technology adoption decision where the retailer chooses the procurement system to minimize the total cost of presenting a shelf-ready product to the 
consumer. This cost is comprised of three parts. First, transaction costs (search, negotiation, and contract monitoring and enforcement, and other costs related to the acquisition of the intermediate input); second, the cost of the intermediate input, which in this case is the cost of the produce from the supplier; and third, transformation costs (including packing, packaging, sorting, delivery, storage, and shrinkage of the product before sale to the consumer).

Three inter-related decisions comprise the procurement strategy. The first decision is how to organize procurement, specifically whether to have centralized or decentralized procurement. Second is the source of produce, whether it be purchased directly from the growing region or from intermediaries in a central wholesale facility. Third, the retailer must choose institutional arrangements ${ }^{1}$ to support the transaction, specifically product standards and relationships with suppliers.

Retailers' procurement strategy decisions tend to exist in patterns, reflecting tradeoffs among different costs that exist among the different procurement strategy combinations. For example, purchases from the growing regions are often seen in combination with a centralized procurement and distribution system and formal relations with suppliers. Another common combination is decentralized purchases from the wholesale market in combination with informal relationships with suppliers. The prior strategy tends to offer lower product acquisition costs but higher transformation costs as the retailer takes on many of the functions otherwise performed by intermediaries. In contrast, decentralized purchases from the wholesale market can reflect higher costs for product acquisition but less transformation costs. The effects of different strategies, and in particular formal and informal relationships with suppliers, are difficult to predict, however, as different types of transaction costs (such as search or quality verification) may have opposing effects.

Three variables are hypothesized to influence the choice of procurement strategy: scale, scope, and specialization. Scale refers to the total throughput volume of fresh produce of a retail firm (indicated by the total sales floor space dedicated to produce) and comes into play in two ways. First is the potential for cost savings from economies of scale

1 "An institutional arrangement is an arrangement between economic units that governs the ways in which these units can cooperate and/or compete." (Williamson 1991) 
particularly through large fixed investments in procurement facilities. Second is the opportunity for a retailer to use market power to reduce costs, most obviously by negotiating lower prices in the acquisition of intermediate products from suppliers or by volume discounts. A large scale of purchases can also potentially help reduce transaction costs if the retailer buys enough from an individual supplier so that the supplier's desire to maintain the retailer as a client serves as an enforcement mechanism for any transaction agreements.

The second variable, scope, refers to the variety of different fresh produce products or items that are marketed by a retail firm. Scope is indicated by the total number of different items carried by the firm. Like scale, scope can offer potential cost savings through investment in large capacity facilities and processes. Economies of scope will offer potential for cost savings if these facilities and processes can work with numerous different types of products at once. Additional savings can also be achieved if retailers tend to purchase numerous products from the same suppliers, giving rise to the potential to negotiate price discounts if "bundles" of products are purchased (analogous to volume discounts). Furthermore, if scope is small, then transaction and transformation expenses may be less important considerations for a retailer who will be dealing with fewer suppliers and fewer products, even as it is buying relatively more volume of each product than a firm of the same scale that has a larger scope.

Specialization refers to the degree to which a retail firm depends on fresh produce for its revenue flow and is indicated by the share of the firm's revenue contributed by fresh produce sales. It is also an important factor determining the relative benefits of different procurement strategies. If produce does not constitute a large portion of the retailer's total revenue, it might prefer to save on transactions and transformation expenses in exchange for a higher purchase price, as the former costs tend to be more demanding of the firm's internal resources (labor, space) than the latter. Conversely, as fresh produce becomes more and more important in a firm's revenues, then the retailer may have an incentive to devote more internal resources to its transformation.

The hypothesized effects of scale, scope, and specialization on firms' choice of procurement organization, source, and institutions are 
summarized in Box 2, and outlined in detail below. It is important to note that differences in the quality of produce merchandise are not addressed here, instead a homogeneous product is assumed. This assumption is defensible on several accounts. First, firms which operate in multiple locations (such as small and large chains and open-air fair vendors, among others) often target diverse clientele with different qualityprice preferences, and thus seek products of varying levels of quality simultaneously, while using a single procurement strategy to obtain these. Second, major variations in produce quality are often reflected in different product forms-such as pre-packaged and pre-cut produce. The current research excludes these different product forms and focuses on bulk produce procurement only. Though differing levels of quality can be found in bulk produce, the variations are not as significant as variations in quality among different product forms.

Box 2. Hypothesized effects of scale, scope, and specialization procurement strategy

\begin{tabular}{|l|c|c|c|}
\hline & $\begin{array}{c}\text { Organization } \\
\text { (Centralization) }\end{array}$ & $\begin{array}{c}\text { Source } \\
\text { (Purchases from Grower) }\end{array}$ & $\begin{array}{c}\text { Relationship \& Standard } \\
\text { (Formal) }\end{array}$ \\
\hline Scale & + & + & + \\
\hline Scope & + & - & No a priori expectation \\
\hline Specialization & + & + & . \\
\hline
\end{tabular}

\section{Hypothesis: Scale, Scope, and Specialization Effects on Organization}

Centralized purchases and distribution are defined as those for which a central authority in the firm (such as the head office) is responsible for the majority of procurement and distribution tasks. These tasks include the decision of what and how much to order, selection of suppliers, submission of product orders, payment to suppliers, and the physical delivery of product to individual retail outlets. A decentralized strategy is one where either each individual store or a third-party is responsible for these activities. 
Centralized purchases usually involve significant investments in physical, logistical, managerial and communications infrastructure. This infrastructure includes a physical purchase and distribution center that can accommodate logistical methods such as cross-docking, a centralized ordering system that links individual stores to the procurement center and the procurement center to buyers (though internet, fax, and other business-to-business communications), and skilled employees who manage the purchasing, distribution, quality control and other functions. As an indicator of the significance of the investment involved to establish a modern centralized procurement system, in 2001 CBD, Brazil's largest retailer, spent approximately US $\$ 10$ million to establish a new purchase and distribution center (with attendant infrastructure) for perishables. In contrast to the centralized procurement system, a decentralized system involves relatively little fixed cost investment as it relies primarily on individual stores assessing their merchandise needs and making purchase orders after an assessment of market conditions. The primary cost savings of a centralized system accrued by firms with a large scale and scope will be associated with product transformation, because, by aggregating the purchases of numerous stores, the centralized system facilitates purchases direct from the growing areas and vertical integration of functions traditionally performed by intermediaries, such as the sorting and combination of different product shipments for delivery to individual stores, and quality control. Retailers with centralized procurement systems make large fixed investments. A firm with a high scale and scope of operations can thus benefit from scale and scope economies and often perform these functions at a lower cost than traditional intermediaries. They can also see reduced transformation costs as they have better control over processes and reduce the time between produce harvest and sale to consumer, thus reducing shrinkage. Thus it is hypothesized that scale and scope will be positively correlated with the centralization of procurement strategies.

A high degree of specialization is also hypothesized to be correlated with the decision to centralize. A highly specialized firm can be expected to have its resources dedicated to specialized procurement activities within the firm, which is consistent with a centralized procurement 
strategy in which a core set of resources (i.e. labor and facilities) are dedicated to procurement and transformation activities for all the stores in the firm.

\section{Hypothesis: Scale, Scope, and Specialization Effects on Source}

Retailers can purchase fresh products from a number of sources and often purchase from a combination of different sources. These sources can be categorized as either wholesale sources or growers. In this analysis, purchases from wholesalers mean that the retailer buys at least $2 / 3$ of its produce from wholesalers who are in the public wholesale markets and distributors who buy from the wholesale markets or growers and distribute to different retailers. If a retailer buys from growers, this means that at least $2 / 3$ of his produce is sourced from growers, including both farmers and grower-packer-shippers who are based in the growing areas and sell both merchandise that they have produced as well as that purchased from other farmers.

The most obvious difference achieved by choice of source is in product acquisition costs. By purchasing from the growing regions (often in combination with centralized purchases in which the retailer integrates traditional intermediary functions), the retailer eliminates a link in the marketing chain, reducing the price it pays for product. There are also potential savings in transaction and transformation costs. With respect to transaction costs, one of the key factors distinguishing growers from wholesale market intermediaries as suppliers is the ease with which substitutes can be found if a supplier fails on any given transaction. In general, wholesale intermediaries are easily substitutable-their concentration in a centralized physical location (the wholesale market) means that alternative suppliers can be found should a specific supplier fail. In contrast, growers tend to be physically dispersed and less easily substitutable. There are also important differences in business practices of the two-a reliance on advance purchase orders submitted to growers, for example, versus more day-of purchases from wholesalers. Thus, buying directly from the growing region can be expected to result in higher fixed transaction costs but lower variables ones, all else held equal. Likewise, the retailer will tend to require more established 
relationships in which product requirements and purchases are fixed in advance which result in high fixed search costs (for the supplier, not the product) but lower costs for monitoring of individual transactions. Thus larger scale retailers are hypothesized to be more likely to buy from growers. The same hypothesis does not hold for scope. A retailer with a large scope will have more products to purchase. Unless individual growers can meet numerous product needs at once, the retailer is more likely to economize on transaction costs by seeking out suppliers who are concentrated in the wholesale market, assuming specific product needs can be accommodated through this market outlet.

A high degree of specialization is hypothesized to increase the likelihood of purchases from the growing region. A firm that relies more on fresh produce for its revenue can be expected to invest more of its limited resources in product acquisition and transformation, particularly if this results in savings on purchase costs due to elimination of intermediaries.

\section{Hypothesis: Scale, Scope, and Specialization Effects on Institutional Arrangements}

The third decision considers the institutional arrangements, specifically relationships with suppliers and quality standards that will support the transaction. Relationships can either be constituted by formal contracts or informal, ongoing relationships. Formal relations include the use of "preferred supplier lists" or registries or formal contracts with suppliers. Informal relations with suppliers include both anonymous ("spot market") relations in which the identity of the supplier is unimportant to the retailer, and ongoing but informal at-will relationships with suppliers. Likewise, the quality standards used can be informal or formal. Informal standards are those that rely on the default public standard (which is subjectively defined and not enforced) or shared understandings between the retailer and supplier of what the retailer's needs are. Formal ones are explicitly defined, with published technical parameters, for example, and monitored and enforced either by the buyer or seller or third party certifiers.

The decision to rely on formal or informal relationships and standards 
are expected to be similarly affected by scale, scope, and specialization. Two reasons underlie this expectation: First, both relationships and standards reflect similar economic characteristics in terms of having high costs to establish and potentially low monitoring and enforcement costs on a per-unit basis. Second, the choices are interdependent. For example, a retailer who imposes a private standard that requires highly specific investments on the part of a supplier (such as investments in green houses or food safety certification), can help to assure the supplier of a market for his product by offering a formal purchase contract. Given the weak institutional environment in Brazil, particularly the lack of enforced public grades and standards for vegetables, the decision to rely on public standards reflects high variable transaction and transformation costs, as good quality product must be searched for, often by physically inspecting the product. Thus, sorting and shrinkage costs will typically be high, even though it will be easy to find suppliers to comply with the less stringent product and relationship requirements. The decision to promulgate private grades and standards, on the other hand, involves high fixed costs of establishing the standards and finding suppliers who are willing and able to meet them. Once they are established, however, monitoring and enforcement costs are reduced, particularly if a formal contractual relationship is maintained. Thus, a firms with a larger scale of operations can be expected to be more likely to rely on formal standards. In contrast, for a retailer with a large scope but limited scale for each item, the high cost of establishing standards for each individual product and the accompanying transaction costs of monitoring and enforcing the standards can be expected to increase the likelihood of relying on a public standard. The effect of specialization in fresh produce on relationships and standards does not carry any prior expectations.

\section{Data \& Methods}

Data are drawn from the results of a survey of 33 retailers in metropolitan São Paulo, conducted in 2002. The survey collected information on the characteristics of the retailers, their product offerings, and procurement strategies for lettuce and tomato. Surveys were conducted by the primary author at the retail site (or headquarters 
for chains) with the firm's head produce buyer as respondent, with the single exception of a large chain which did not permit a site visit but responded to the questionnaire over email. Interview requests were made by the primary author on the basis of "cold calling" to retailers listed in the phone book, except in the case of open air fair vendors in which initial visits and interview requests were made in person, and large chains which were referred through industry contacts. An effort was made to obtain representation by each of the major types of retailers in São Paulo, these being large chains, small and medium-sized chains and independents, discount green grocers, and open-air fair vendors.

The data are analyzed in two different ways. First, looking at tomatoes and lettuce separately, the effects of scale, scope and specialization on retailers' choices of organization, institutional arrangements and sources underlying their procurement strategies are addressed using statistical tests for differences in means between groups. Second, cluster analysis is used to group retailers on the basis of their choices of how to organize, source, and govern their procurement. Separate groups with characteristic procurement strategies are distinguished for tomato and lettuce, and hypotheses regarding the influence of scale, scope, and specialization on these strategies are addressed using tests for differences in means.

The non-normal distribution of the variables and the small sample size make the Mann-Whitney rank sum test to test for differences between groups on the basis of the hypothesized variables appropriate (SPSS, 1999). Results are considered to be statistically significant at a $10 \%$ confidence level, owing to the small size of the sample.

\section{Results \& Discussion}

\section{Scale, scope \& specialization effects on specific procurement strategy aspects}

Boxes 3 and 4 report the results of hypothesis testing for the effects of scale, scope, and specialization on specific components of retailers' strategies for the procurement of tomatoes and lettuce, respectively. For tomatoes, increases in both scale and scope are correlated with reliance 
on centralized procurement, while specialization has no statistically significant effect. These results are consistent with the hypotheses. For lettuce, in contrast, none of the hypothesized variables are associated with an increase in use of centralized procurement-indeed only one firm in the sample relied on such an organizational strategy for procurement. Comparing lettuce to the results for tomatoes suggests that in the current environment, the characteristics of lettuce are such that potential efficiency gains to procurement through centralization are insignificant compared to the costs of such a strategy-most likely reflected in high rates of product spoilage and lower quality (hence lower sale prices), particularly given the lack of a cold chain for the product.

Box 3. Tomato procurement strategies by firm scale, scope \& specialization

\begin{tabular}{|l|l|c|c|c|c|c|c|}
\hline \multirow{2}{*}{ Variable } & \multicolumn{2}{c|}{ Organization } & \multicolumn{2}{c|}{ Source } & \multicolumn{2}{c|}{ Governance } \\
\cline { 3 - 9 } & Cent. & Decent. & Grower & Wholesale & Formal & Informal \\
\hline Scale & Mean & 23855 & 841 & 25675 & 308 & 43923 & 1365 \\
\hline (FFV M2) & P-value & \multicolumn{2}{|c|}{0} & \multicolumn{2}{|c|}{0.07} & \multicolumn{2}{c|}{0.019} \\
\hline Scope & Mean & 206 & 125 & 206 & 94 & 512 & 100 \\
\hline (\# items) & P-value & \multicolumn{2}{|c|}{0.023} & \multicolumn{2}{|c|}{0.044} & \multicolumn{2}{c|}{0.002} \\
\hline $\begin{array}{l}\text { Specialization } \\
\text { S\% revenue } \\
\text { from FFV) }\end{array}$ & Mean & $70 \%$ & $61 \%$ & $63 \%$ & $60 \%$ & $15 \%$ & $66 \%$ \\
\hline
\end{tabular}

Box 4. Lettuce procurement strategies by firm scale, scope \& specialization

\begin{tabular}{|l|l|c|c|c|c|c|c|}
\hline \multirow{2}{*}{ Variable } & \multicolumn{2}{|c|}{ Organization } & \multicolumn{2}{c|}{ Source } & \multicolumn{2}{c|}{ Governance } \\
\cline { 3 - 9 } & Cent. & Decent. & Grower & Wholesale & Formal & Informal \\
\hline Scale & Mean & 4950 & 6895 & 12,285 & 213 & 65840 & 948 \\
\hline (FFV M2) & P-value & \multicolumn{2}{|c|}{0.296} & \multicolumn{2}{|c|}{0.055} & \multicolumn{2}{c|}{0.002} \\
\hline Scope & Mean & n.a. & 150 & 153 & 159 & 368 & 142 \\
\hline (\# items) & P-value & \multicolumn{2}{|c|}{0.64} & \multicolumn{2}{|c|}{0.374} & \multicolumn{2}{c|}{0.052} \\
\hline Specialization & Mean & $5 \%$ & $60 \%$ & $52 \%$ & $91 \%$ & $10 \%$ & $70 \%$ \\
\hline $\begin{array}{l}\text { (\% revenue } \\
\text { from FFV) }\end{array}$ & P-value & \multicolumn{2}{|c|}{0.709} & \multicolumn{2}{|c|}{0.037} & \multicolumn{2}{|c}{0.011} \\
\hline
\end{tabular}


The results of retailers' sourcing strategies for tomatoes also support the hypothesis that scale and scope encourage purchases from the growing region, while specialization again has no statistically-significant correlation. Considering that tomatoes were sourced from both São Paulo and outside regions, it is possible that the lack of statistical significance of the effect of specialization in the choice of the tomato source is an indication that both growing area and wholesale market have relative strengths or that, in fact, they do not have any outstanding differences. For example, as previously noted, all tomatoes sold pass through a classification plant owned by a grower-shipper intermediary, and many of these firms have operations in regions other than São Paulo state. This flexibility could, along with other factors, contribute to different sources being interchangeable or differentiated on the basis of other factors. In contrast, for lettuce, increases in scale and decreases in specialization are shown to be correlated with purchase from the growing region, while scope has no statistically significant effect.

There was little variation within firms with respect to their choices of formal or informal institutional arrangements. With the exception of only two firms in the sample, all firms that relied on formal relationships with their suppliers likewise had formal standards, and vice versa. Thus, the analysis focused on the choice of relationship alone, representing institutional arrangements in general. For both lettuce and tomatoes, scale and scope are both positively correlated with reliance on formal governance of relationships with suppliers. For both tomatoes and lettuce, specialization is negatively correlated with reliance on formal relations with suppliers. It is possible that the negative correlation is indicative of more specialized firms having sunk, social capital investments in relationships, making formal governance unnecessary for their needs.

\section{Scale, scope \& specialization effects on procurement strategy patterns}

Cluster analysis of retailers' choices of procurement strategy for tomato and lettuce led to the identification of two groups, each with a characteristic procurement strategy. The first group, into which $21 \%$ of the tomato retailers fell, relied on centralized organization or procurement, 
purchases from the growing region, and formal relationships with suppliers. The second group accounted for the remainder of the retailers (79\%) and was characterized by reliance on decentralized organization, purchases from the wholesale market, and informal relations with suppliers. The two general procurement strategies identified for lettuce were largely similar-one group purchased from the wholesale market, and another group purchased from the growing region, but in both cases purchases were decentralized and informal relationships with suppliers were predominant. Decentralized purchases for lettuce are common due to the highly perishable characteristic of the product, which encourages direct distribution among stores rather than routing the product through a central private distribution center, particularly given the lack of a cold chain.

Boxes 5 and 6 summarize the test results for differences in groups belonging to each cluster for tomatoes and lettuce, respectively. As can be seen, scale, scope, and specialization have differing influences depending on the product. For tomatoes, a large scale and scope of operations has a strong correlation with the use of a centralized procurement system that sources from the growing region with formal relationships with suppliers. Specialization has no statistically significant effect however. For lettuce, consistent with the results from tomato data, a larger scale of operations is correlated with purchases from the growing region. However, in contrast to tomatoes, scope is not correlated with purchases from the growing region, while those firms less specialized in fresh produce sales also purchase from the growing region with more frequency than the highly specialized firms. This last result runs contrary to the hypothesis that highly specialized firms would have the incentive to buy directly from the growing region to save on purchase and transaction costs and to ensure the highest possible quality. A possible explanation for this result is that highlyspecialized firms may be more traditional in nature, and so may be embedded in long-term relationships with suppliers at the wholesale market, and/or they may lack the infrastructure (such as trucks) or scale necessary to buy from the growing region. In either case, this would be an indication of impediments to what might be competitivenessenhancing adjustments to their strategies by these retailers. 
224 - Scale, Scope, and Specialization Effects on Retailers' Procurement Strategies: Evidence from the Fresh Produce Markets of São Paulo

Box 5. Scale, scope and specialization effects on procurement strategy for tomato

\begin{tabular}{|c|c|c|c|}
\hline \multicolumn{2}{|l|}{ Variable } & $\begin{array}{c}\text { Centralized, } \\
\text { Grower, } \\
\text { Formal }\end{array}$ & $\begin{array}{c}\text { Decentralized, } \\
\text { Wholesale, } \\
\text { Informal }\end{array}$ \\
\hline \multicolumn{2}{|c|}{ Participation in group } & $21 \%$ & $79 \%$ \\
\hline \multicolumn{4}{|c|}{ Scale, scope \& specialization by cluster type } \\
\hline \multirow{2}{*}{$\begin{array}{l}\text { Scale } \\
(\text { FFV M2) }\end{array}$} & Mean & 35,508 & 942 \\
\hline & P-value & \multicolumn{2}{|c|}{0.001} \\
\hline \multirow{2}{*}{$\begin{array}{l}\text { Scope } \\
\text { (\# items) }\end{array}$} & Mean & 246 & 98 \\
\hline & P-value & \multicolumn{2}{|c|}{0.027} \\
\hline \multirow{2}{*}{$\begin{array}{l}\text { Specialization } \\
\text { (\% revenue from } \\
\text { FFV) }\end{array}$} & Mean & 55 & 63 \\
\hline & P-value & \multicolumn{2}{|c|}{0.618} \\
\hline
\end{tabular}

Box 6. Scale, scope and specialization effects on procurement strategy for lettuce

\begin{tabular}{|c|c|c|c|}
\hline \multicolumn{2}{|l|}{ Variable } & $\begin{array}{l}\text { Decentralized, } \\
\text { Grower, } \\
\text { Informal }\end{array}$ & $\begin{array}{l}\text { Decentralized, } \\
\text { Wholesale, } \\
\text { Informal }\end{array}$ \\
\hline \multicolumn{2}{|c|}{ Participation in cluster } & $59 \%$ & $41 \%$ \\
\hline \multicolumn{4}{|c|}{ Scale, scope \& specialization by cluster type } \\
\hline \multirow{2}{*}{$\begin{array}{l}\text { Scale } \\
\text { (FFV M2) }\end{array}$} & Mean & 14737 & 212 \\
\hline & P-value & \multicolumn{2}{|c|}{0.023} \\
\hline \multirow{2}{*}{$\begin{array}{l}\text { Scope } \\
\text { (\# items) }\end{array}$} & Mean & 176 & 159 \\
\hline & P-value & \multicolumn{2}{|c|}{0.129} \\
\hline \multirow{2}{*}{$\begin{array}{l}\text { Specialization } \\
\text { (\% revenue from } \\
\text { FFV) }\end{array}$} & Mean & $44 \%$ & $91 \%$ \\
\hline & P-value & \multicolumn{2}{|c|}{0.009} \\
\hline
\end{tabular}

\section{Conclusion}

Tests of hypotheses regarding the relationship between retailers' scale, scope, and specialization and their procurement strategies for fresh produce largely supported hypotheses. Scale and scope were positively correlated with reliance on procurement strategies that were 
patterned on centralized procurement, purchases from the growing area, and formal institutions to govern procurement of tomatoes. Firms purchasing lettuce directly from the growing regions had a significantly higher scale and lesser degree of specialization than those purchasing from wholesale markets, despite there being no difference in their organization or governance methods.

Decomposing the procurement strategy provided further insight into the effects of scale, scope, and specialization on specific aspects of the strategy. Overall, the effects of scale on procurement strategy decisions were as hypothesized. Scope was shown to have similar effects as scale, being associated with an increase in purchases from the growing region and greater reliance on formal relations. Specialization, on the other hand, was shown to be negatively correlated with these practices.

The significance of these results lies in the insight they provide into the diverse procurement strategies employed by retailers in São Paulo's fresh product markets and their affirmation of the relevance of these diverse strategies to the economic vitality of these heterogeneous actors. The significance of scale, scope, and specialization in various aspects of retailers' procurement strategies is supportive of the argument that the divergence of small retailers' procurement strategies from large firms' strategies is not necessarily an indication of their being less efficient. Instead, the existence of diverse procurement strategies among firms can be argued to exist on efficiency grounds. This result is consistent with the findings of other research on retail strategies in Brazil, such as Farina et al (cited previously), which show the importance of diverse merchandising strategies to accommodate the great heterogeneity of demand among consumers in metropolitan São Paulo (which is also present in the majority of large urban markets worldwide). Two important extensions to this research would be to: 1) undertake further analysis with a larger sample, enabling econometric testing for interaction among the variables and procurement strategy components, and 2) using measures of firm performance to test for the relative efficiency of different strategies holding scale, scope, and specialization constant. It would also be worthwhile to undertake further research on how other factors, such as the location of a retail establishment and its clientele, affect is procurement strategies. 


\section{References}

Arnold, S. J. and M. N. Luthra (2000). "Market Entry Effects of Large Format Retailers: A Stakeholder Analysis." International Journal of Retail \& Distribution Management 28(4): 139-154.

Farina, E. M. M. Q. (2002). “Consolidation, Multinationalization, and Competition in the Supermarket and Processing Sectors in Brazil: Impacts on Horticulture and Dairy.” Development Policy Review 20(4): 441-457. (NÃO ESTÁ CITADO NO TEXTO)

Farina, E. M. M. Q., R. Nunes, Monteiro Guilherme F. de A. (2004). Modeling Produce Procurement and Merchandising Strategies of Traditional Retailers in the Face of Competition with Supermarkets in the São Paulo Region. 88th Seminar European Association of Agricultural Economics on Retailing and Producer-Retailer Relationships in the Food Chains, Paris.

Green, R., T. d. N. Vaz, et al. (1997). Supermarkets and Coordination Forms in the Food Sector. Vertical Relationships and Coordination in the Food System, Piacenza, Italy, Universitá Cattolica del S. Cuore, Istituto de Economia Agro-alimentare, Scuola di Specializzacione e Master in Economia Agro-alimentare (SMEA).

Loseby, M. (1997). Vertical Coordination in the Fruit and Vegetable Sector: Implications for Existing Market Institutions and Policy Instruments. Paris, OECD: 34.

Mainville, D. Y., D. Zylbersztajn, E. Farina, T. Reardon. (2005). “Determinants of Retailers' Decisions to Use Public or Private Grades and Standards: Evidence from the Fresh Produce Market of São Paulo Brazil." Food Policy 30(3).

Reardon, T. and J. Berdegué (2002). "The Rapid Rise of Supermarkets in Latin America: Challenges and Opportunities for Development." Development Policy Review 20(4): 371-388.

Shaw, S. A. and J. Gibbs (1999). "Procurement Strategies of Small Retailers Faced with Uncertainty: An Analysis of Channel Choice and Behavior." The International Review of Retail, Distribution and Consumer Research 9(1): 93-109. 
Williamson, O. J. (1991). "Comparative Economic Organization: The Analysis of Discrete Structural Alternatives.” Administrative Science Quarterly 36: 269-96. 